\title{
CLUSTER DEVELOPMENT OF AZERBAIJANI TERRITORIES LIBERATED FROM THE ARMENIAN OCCUPATION: CHOICE OF MODEL
}

*Institute of Control Systems of Azerbaijan National Academy of Science, Baku, Azerbaijan

\begin{abstract}
Анотація. Відродження території Карабаху є першочерговим завданням на шляху подальшого зміцнення політичного та економічного суверенітету Азербайджанської Республіки. На звільнених від вірменської окупації територіях у найкоротші терміни планується забезпечити безпечне $i$ гідне життя для вимушених переселенців, провести відновлювальні роботи в усіх сферах, а також завдяки ефективній діяльності задати імпульс сталого зростання добробуту корінного населення, що повертається. Сучасна практика кластерного освоєння територій випереджсаючого розвитку, що проводиться в різних країнах світу, характеризується синергетичним ефектом від максимального використання регіональних ресурсів, що дозволяє за мінімальний термін досягти значноі економічної вигоди. В рамках кластерного підходу проєкт "розмімується» в певному секторі кластера і реалізується на основі відпрачьованого механізму з урахуванням сочіально-економічних, політичних і правових аспектів. Саме в межах ивого сектора створюються сприятливі умови для реалізаиії даного проєкту, за рахунок яких, власне, досягається синергетичний ефект $i$ забезпечується бажаний результат. Кластерний розвиток звільнених від вірменської окупації територій передбачає участь держави, у тому числі на рівнях галузевих органів виконавчої влади, регіональних органів державної влади та органів місиевого самоврядування, а також в особі державних інститутів розвитку та інституційних інвесторів проєктів комплексного розвитку - фондів прямих інвестицій і провідних системоутворюючих банків. Іншими важливими факторами даного процесу можуть і повинні стати резиденти інновачійних кластерів і технопарків, провідні азербайджанські забудовники, представники бізнес-структур, а також приватні інвестори, зацікавлені у портфельних інвестиціях. У рамках иьього підходу пропонується модель економічного кластера для прискореного розвитку звільнених від вірменської окупаиії територій Азербайджану.
\end{abstract}

Ключові слова: регіональний кластер, модель кластера, показники значущості кластера, синергетичний ефект.

Abstract. The regeneration of the territory of Karabakh is the primary task on the way to further strengthening the political and economic sovereignty of the Republic of Azerbaijan. In the territories liberated from the Armenian occupation, it is planned to provide a safe and dignified life for internally displaced persons in the shortest possible time, to carry out creative and restoration work in all areas, as well as to run effective activities for setting an impulse for a sustainable growth in the well-being of the returned native population. The modern practice of clustering the territories of advanced development, carried out in different countries, is characterized by a synergistic effect from the maximum use of regional resources, which makes it possible to achieve significant economic benefits within a minimum period. Within the framework of the cluster approach, the project is "placed» in a specific sector of the cluster and is implemented on the basis of a worked-out mechanism, taking into account socio-economic, political and legal aspects. It is within this sector that favorable conditions are created for the implementation of the project, due to which, in fact, a synergistic effect is achieved and the desired output is provided. Cluster development of the territories liberated from the Armenian occupation provides for state participation, including at the levels of sectoral executive authorities, regional government and local authorities, as well as in the person of state development institutions and institutional investors in integrated development projects - direct investment funds and leading systemically important banks. The residents of innovation clusters and technology parks, leading Azerbaijani developers, representatives of business structures, as well as private investors interested in portfolio investments can and should become other important actors in this process. Within this approach, a model of an economic cluster is proposed for the accelerated development of the territories of Azerbaijan liberated from the Armenian occupation.

Keywords: regional cluster, cluster model, cluster significance indicators, synergistic effect. 


\section{Introduction}

Under market relations it is impossible to manage the economy in the paradigm of sectoral logic, which has dominated the post-Soviet space for many decades. The concept of «industry», as an object of management, is irrevocably outdated and is gradually being excluded from professional discourse. Nevertheless, there are still specialists who form strategies for regional development in terms of sectoral logic, i.e. in terms of subjects and objects of management. Moreover, traditional financing of regional projects provides for the phased and separate development of investments, which sometimes becomes the primary reason for the «freezing» of the process of financing projects and, accordingly, the suspension or even refusal of their implementation. Within the framework of the cluster system, it is possible to provide flexible financing of projects. Due to the presence of a consolidated budget of the economic cluster, it is possible to quickly and optimally redistribute limited resources between its constituent projects, both those continuing their life cycle and newly implemented ones. Thus, for the comprehensive regeneration of the territory of Karabakh, it is proposed to apply a cluster approach to the development of territories, dictated by the primary tasks and development prospects formulated by President of the Republic of Azerbaijan Ilham Aliyev.

The aim of the work is to analyze the world practice of clustering of regions and to choose a model of an economic cluster for the accelerated socio-economic development of the territories of Azerbaijan liberated from Armenian occupation.

\section{M. Porter's system of determinants}

M. Porter's cluster approach to increasing the competitiveness of the country suggests an indirect influence on its economic development through the creation of conditions for business development [1]. M. Porter examines the competitiveness of the country as a whole through the prism of the international competitiveness of production clusters that unite local companies from different industries and effectively use the internal resources of the state. At the same time, the founder of the theory of economic development M. Porter explains the reason for the success of the separate country in the context of the following four properties (determinants) that form a competitive environment for local companies:

- Factor conditions that are necessary for successful competition in this industry. These are the qualified workforce of a certain profile and natural resources, scientific and information potential, infrastructure, quality of life and capital.

- Conditions of domestic demand for the offered goods (services), implying the quality of demand, compliance with the existing trends in the development of demand in the world market, the development of the demand volume.

- Related and supporting industries which implies the presence or absence in the country of related and/or supporting industries capable of providing raw materials, semi-finished products and equipment, as well as ensuring the sale of raw materials, equipment and technologies.

- Firm strategy, structure and rivalry, i.e. what are the conditions in the country that determine how firms are created and managed and what is the nature of competition in the domestic market.

M. Porter developed a fully-connected system of such determinants (Fig. 1) that reflects a competitive environment which implies the availability of:

- resources and professional skills necessary for a firm to gain a competitive advantage;

- information about the opportunity to gain a competitive advantage and the areas of application of the resources and skills available to the firm;

- the corporate goal of the managers and staff of the firm participating in the competition; 

dating.

- potential that allows the firm to invest in certain activities and periodically engage in up-

As seen from Fig. 1, Porter's system of determinants figuratively looks like a rhombus. Actually, its name follows «competitive rhombus» according to the number of main groups of competitive properties, or, as the author himself called it, «diamond». In addition to the indicated determinants, two more side properties are taken into account - two variables that significantly affect or may affect the situation in the country (region). These are random events beyond the control of company management (for example, external sanctions, natural phenomena and other force majeure events) and possible changes in the political situation in the country.

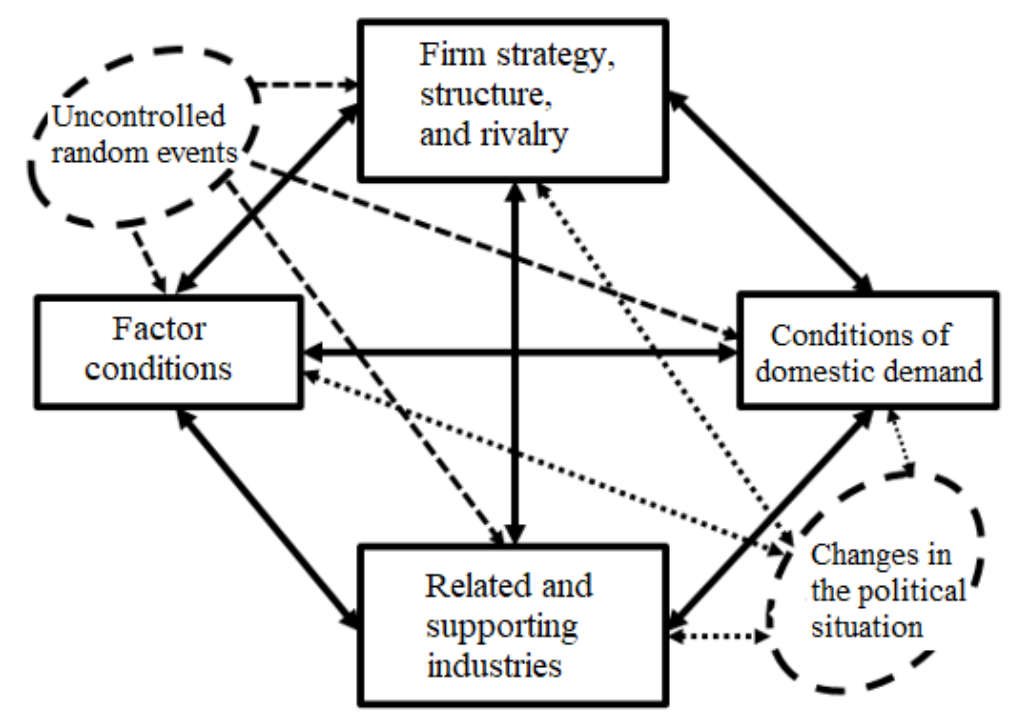

Figure 1 - Competitive rhombus as an environment for economic development

In post-industrial countries the system of determinants of competitive advantage has become a methodological basis for the formation of clusters that incorporate local companies from different industries. According to [2], a cluster is a set of geographically close and cooperating companies (manufacturers, suppliers, etc.), as well as related organizations (educational centers, government authorities, infrastructure companies, etc.). By interacting within the cluster, companies contribute to increasing the competitiveness of each other and, thus, position this cluster as a growth point for the domestic market on the scale of the state economy.

Artificial formation of a regional cluster is a long and resource-intensive process. Therefore, identifying the types of activities in the region, on the basis of which the creation of the cluster will be the most effective, is a very important stage. Currently, to identify and evaluate cluster initiatives there are applied methods that use qualitative estimates (based on indirect information and expert data) and empirical (based on the analysis of official state statistics), among which it is necessary to note the modified approaches of M. Porter [2] and the European Cluster Observatory (ECO) [3]. Qualitative assessment methods allow for a more detailed and relatively accurate identification of clusters in a particular region. Nevertheless, there appear questions about the objectivity of expert data and, as a result, problems arise with the verification of the final results. Therefore, to identify and assess potential clusters, the ECO Methodology is increasingly being used, which includes the following three key indicators:

- Size which is defined as a share of the region in total employment in the cluster group by the country. If a region falls into $10 \%$ of regions leading by this indicator, then the cluster is assessed as significant.

- Specialization which is determined by the localization quotient $(L Q)$. If $L Q>1$, then the cluster is assessed as significant. 
- Focus which is set based on the share of the cluster in total employment in the region. If the cluster is included in $10 \%$ of clusters of the same category, which account for the largest share of total employment in the given region, then it is assessed as significant.

To calculate the given indicators, the following formulas of M. Porter are used in the ECO Methodology [2]:

$$
\begin{gathered}
\text { Size }=\frac{E m p_{i g}}{E m p_{i}}, \\
L Q=\left[\frac{E m p_{i g}}{E m p_{g}}\right] /\left[\frac{E m p_{i}}{E m p}\right], \\
\text { Focus }=\frac{E m p_{i g}}{E m p_{g}},
\end{gathered}
$$

where $E m p_{i g}$ is a number of people employed in $i$-th sector of the $g$-th region; $E m p_{i}$ is a number of people employed in $i$-th sector of economy; Emp $p_{g}$ is the total number of people employed in $g$-th region; Emp is the total number of people employed in the country.

Accordance with at least one criterion means that the cluster group in the region is significant. At the same time, the ECO Methodology makes it possible to assess significant cluster groups in the region by the degree of development (strength). Accordance with each criterion means assigning one «star» to the cluster group (maximum, respectively, three «stars»). The number of «stars» determines the strength of the cluster group.

\section{Cluster models used in economically developed countries}

Despite the ongoing process of globalization and pervasive transnationalization, the cluster approach to the development of territories of advanced growth does not lose its topicality. On the contrary, this approach allows the region to increase its competitiveness through the use of local characteristics. In particular, M. Porter provides numerous arguments in support of the cluster approach. For example, clustering of a specific territory increases the number of local taxpayers and, thus, increases the tax base, since unlike vertical corporations, management centers of SMEs are usually located in the same territory as their business. This, in its turn, becomes an effective tool for interaction between local bodies and business. What is more, there appears an opportunity to diversify the economic development of the region. As a result, the personnel infrastructure for business is improved, opportunities for research and development appear in order to reduce internal costs, and the prerequisites for international markets entry are created.

For successful clustering of a specific territory at the initial stage it is necessary to mutually coordinate the regional strategy with target programs for the development of individual clusters. This implies defining key growth points of the economy of the region and identifying the opportunities and interests of business structures for the development of these key growth points. In other words, the formation of promising cluster models and the planning of their subsequent development (self-organization) should proceed within the framework of the chosen regional strategy.

The world practice of clustering the territories of advanced development demonstrates numerous examples of increasing the competitiveness of regions $[4,5]$. In post-industrial countries, such as the USA, Japan, Germany, Great Britain, Finland, France, Canada, etc., territorial clusters have become a traditional form of organizing business communities in the form of agglomerations and/or conglomerations. It is no secret that the high level of competitiveness of the- 
se countries in the world market is based on the strong positions of territorial clusters, which greatly contribute to the optimization of the management of the national economy. It is enough to give an example of Silicon Valley (California, the USA) where more than 80000 companies, several large world-renowned universities and dozens of research centers are successfully operating. This is a vivid example of a competitive environment according to M. Porter, where, within the framework of individual territorial clusters, academic centers fruitfully interact with business under the financial patronage of hundreds of regional banks.

Analysis of foreign experience in promoting cluster policy in regions of outstripping growth revealed two main cluster models: liberal and dirigist. The liberal cluster model is typical for post-industrial countries where liberal economic policies traditionally dominate (for example, the US, Great Britain, Canada, Australia, etc.). The essence here is that the cluster is perceived as a market mechanism where the role of the state in its self-organization is minimized, for example, to remove obstacles. The liberal approach implies self-organization of clusters from the depths of structures that are initially formed due to the needs of the market. The dirigistic cluster model is typical for post-industrial countries whose governments are actively involved in the process of economic management (for example, Germany, France, Sweden, Finland, China, Japan, Austria, India, South Korea, etc.). The governments of these countries are closely involved in the economic life and carry out an important role in the formation of territorial clusters, which implies the implementation of the package - from the choice of target programs for the development of territorial clusters and their financing to the creation of factors necessary for their subsequent self-organization. In other words, the government chooses the region for clustering, creates a suitable infrastructure for priority clusters and sets the amount of their funding.

Comparative analysis of the peculiarities of cluster organization in post-industrial countries allows to identify five most typical approaches: the Italian model, the Japanese model, the Finnish model, the American model and the Indian-Chinese model. Moreover, each model includes the following six key characteristics of the cluster: 1) the degree of market relations and competition; 2) the presence of a leading firm; 3) small business development; 4) innovation; 5) internationalization; 6) the presence of foreign capital. These characteristics form one or another cluster model from the given list by their certain combination (proportions). The following figures show the main outlines of these models [6].

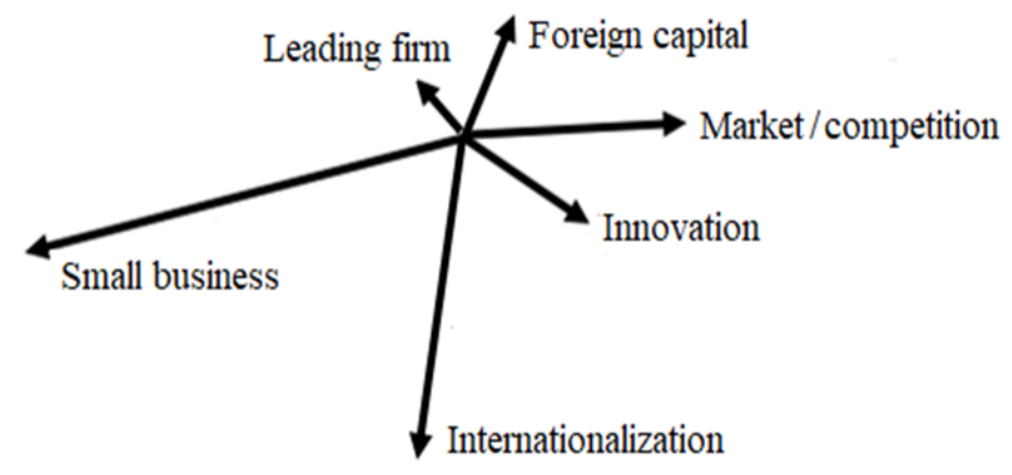

Figure 2 - The Italian cluster model

So, from Fig. 2, which reflects the liberal Italian model, it can be seen that the corresponding cluster consists of a large number of small companies (figuratively, this is the longest ray of «small business») which try to increase their competitiveness through various associations (conglomerations). This model is used in the production of goods of the low technological level under signifi-

cant differentiation and fluctuations in consumer demand.

Fig. 3, which reflects the Japanese model, demonstrates that the cluster implies the presence of the leading firm (figuratively, this is the longest ray of the «leading firm») distinguished by a high production scale, that integrates numerous suppliers at various stages of the technological chain. Therefore, this cluster model is applied for the production of technologically complex products. In this case, self-organization of the cluster is accompanied by high production costs which must be compensated by the larger volume of sales. Obviously, this cluster model is a dirigist one. 
Fig. 4, in its turn, reflects the Finnish dirigistic cluster model. As can be seen from the figure, this model is distinguished by high levels of business internationalization and applied innovations (figuratively, these are two long rays «Internationalization» and «Innovation»). The model can be applied in small export-oriented countries with the deficit in natural resources.

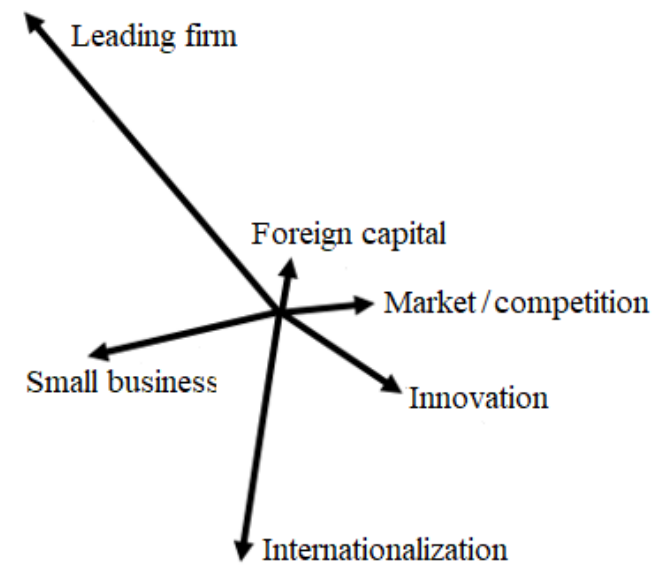

Figure 3 - The Japanese cluster model

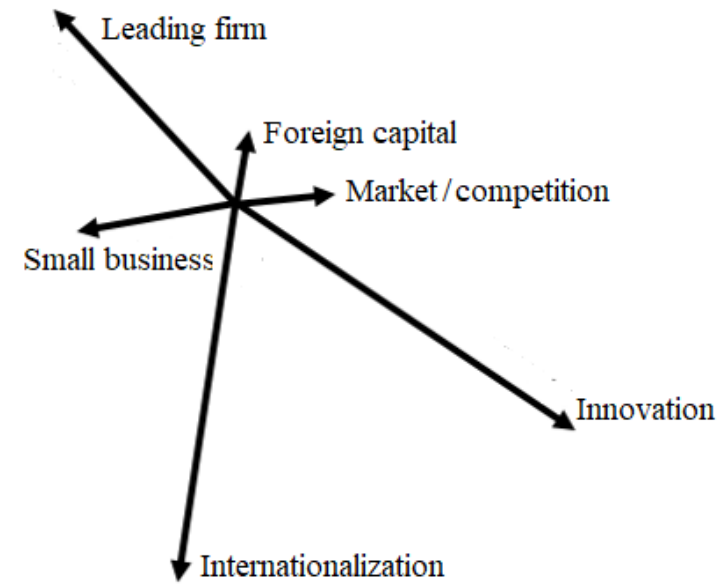

Figure 4 - Finnish cluster model

Fig. 5 shows the liberal American model of the cluster which reflects a high competition between the suppliers in the environment where most relationships are regulated by the market (figuratively, this is the longest ray «Market/competition»). The cluster is formed relative to the parent company, the costs of which are constantly decreasing due to increasing production volumes and intense competition between the supplying firms. As a result, the cost of the final product decreases, the level of competitiveness of the parent company and the cluster as a whole grows.

In the Indian-Chinese dirigistic model of the cluster (Fig. 6), the main role is assigned to foreign capital (figuratively, this is the longest ray of «Foreign capital»), the investment of which, as a rule, is accompanied by the introduction of modern technologies and the promotion of the final product to world markets.

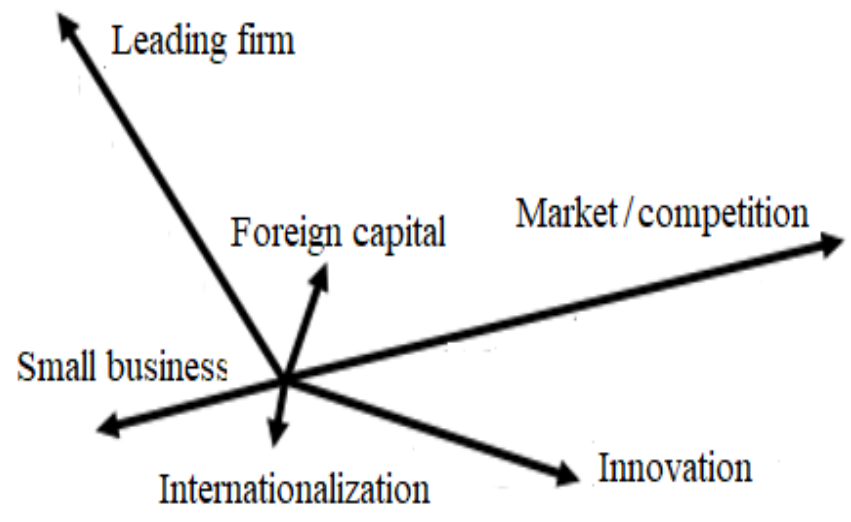

Figure 5 - The American cluster model

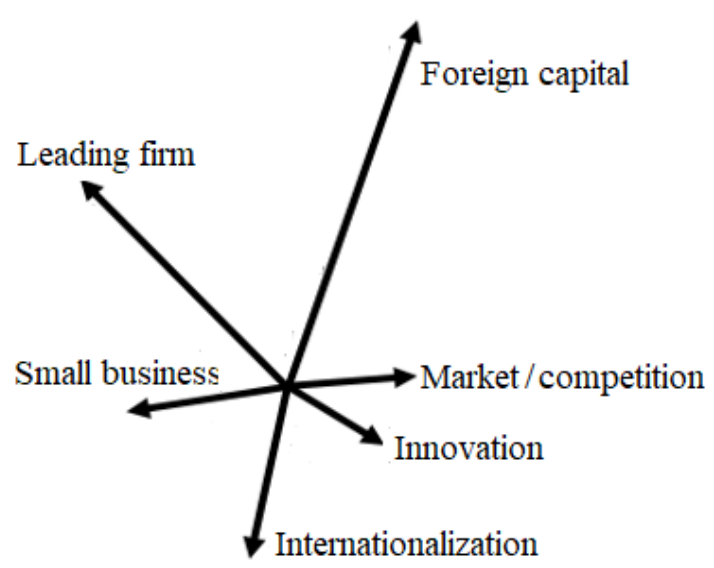

Figure 6 - The Indian-Chinese cluster model

\section{Basic cluster model for the development of Azerbaijani territories liberated from the Armenian occupation}

The international experience of introducing cluster approaches to the development of territories of advanced growth and, in particular, the analysis of the above models of clusters demonstrate the possibility and necessity of conducting a national cluster policy for the revival of the liberated 
territories of Azerbaijan, which subsequently can and should become points of growth for the domestic market. Taking into account the dirigistic model of the economy of Azerbaijan, which determines the strong involvement and active participation of the government in the economic life of the country, attention should be paid to the dominant importance of state structures and research centers in the formation of the cluster strategy for the development of territories.

In one of his speeches, President of the Republic of Azerbaijan Ilham Aliyev unambiguously expressed his vision of approaches to the revival of the territories of Azerbaijan liberated from the Armenian occupation. In particular, at various information and political events, the President has repeatedly invited companies from friendly countries to actively participate in the process of restoring the liberated territories, which would ensure a high level of internationalization of business in the development of public investments allocated for the assimilation of the liberated territories.

On January 26, 2021, during the reception of R. Nabiyev in a video format on the occasion of his appointment as the Minister of Transport, Communications and High Technologies, President Ilham Aliyev emphasized that cities and villages in the liberated territories should be re-created based on the concepts of «Smart city» and «Smart village». Thus, the President indicated the need to use innovative (digital) technologies in the implementation of urban planning and the implementation of regional projects.

Therefore, guided by the directives of President of the Republic of Azerbaijan Ilham Aliyev and taking into account the analysis of the given cluster models in adaptation to the national

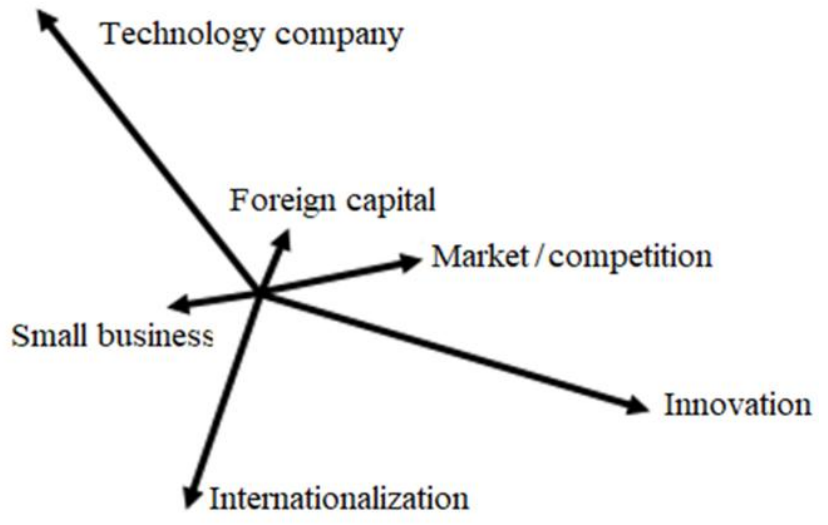

Figure 7 - The proposed cluster model for the development of the liberated territories interests of Azerbaijan, a regional cluster model is proposed. On the one hand, it assumes the active participation of a large technology company offering its innovations, and, on the other hand, provides comprehensive support to government authorities. In this sense, the most suitable model is a dirigistic model of the regional cluster, which is shown in Fig. 7 and distinguished by high levels of business internationalization and innovation. The model in Fig. 7 is somewhat similar to the dirigistic Finnish cluster model. However, in contrast to it, the proposed model is based on rich domestic natural resources and is focused on both external and internal markets.

To estimate the total economic (synergetic) effect from the functioning of this cluster, the following universal three-dimensional mathematical model can be applied:

$$
B=\sum_{k=1}^{n}\left[f_{k t}(x, y, z)-f_{k 0}(x, y, z)\right]
$$

where $B$ is the profit based on the results of the consolidated work of the cluster; the variable $x$ denotes the number of structures needed to implement projects; $y$ denotes the conditions for the implementation of projects, taking into account risks; $z$ denotes the terms of project implementation; the function $f_{k 0}(x, y, z)$ reflects the volume of the initial investment required to implement the $k$-th project; $f_{k t}(x, y, z)$ reflects the amount of income received at the end of the implementation of the $k$-th project; $n$ is a number of projects implemented within this cluster.

Formula (4) can be used for the step-by-step calculation of the economic potential of the cluster at different time intervals (for a decade / a month / a quarter / a year), and, thereby, it can digitize the life cycle of cluster initiatives. But for this it is necessary to correctly identify the 
function $f(x, y, z)$. One of the effective ways is to approximate this function, for example, by a multilayer feedforward neural network, which is a subject of another research.

\section{Conclusions}

The cluster approach to the development of the territory provides for the solution of a whole range of measures, the primary of which are the choice of tools to support integrated development and the creation of conditions for the development (self-organization) of clusters, including specific conditions for the implementation of effective cluster projects by contractors. In order to create a competitive environment and diversify the economy in the region, great responsibility is laid on small and medium-sized businesses, as well as on innovative territorial development clusters as a base for training professional personnel, ensuring technological breakthroughs and attracting the investments.

Cluster assimilation of the liberated territories provides for state participation, including at the levels of sectoral executive authorities, regional government authorities and local governments, as well as in the person of state development institutions, institutional investors in integrated development projects - direct investment funds and leading strategic banks. Other important actors in this process can and should be residents of innovation clusters and technological parks, leading Azerbaijani developers, representatives of small and medium-sized businesses, as well as private investors interested in portfolio investments.

\section{REFERENCES}

1. Porter M. The Competitive Advantage of Nation. Basingstoke: Macmillan, 1990. 21 p.

2. Porter M. The economic performance of regions. Regional Studies. 2003. Vol. 37. P. 549-578.

3. Crawley A., Pickernell D. An appraisal of the European Cluster Observatory. European Urban and Regional Studies. 2012. N 19 (2). P. 207-211.

4. Sölvell Ö. Clusters. Balancing evolutionary and constructive forces. Stockholm, Sweden: Ivory Tower Publishers, 2008. 141 p.

5. Ketels Ch., Lindqvist G., Solvell O. Strengthening Clusters and Competitiveness in Europe. The Role of Cluster Organizations. 2012. UDC: http://gosbook.ru/node/84334 (accessed 11.01.2021).

6. Aleynikova I.S., Vorobyev P.V. et al. Models of the organization of regional industrial clusters: an overview of international experience. Analytical report N 2. Yekaterinburg: Center for Regional Economic Research, Faculty of Economics, Ural State University, 2008. 31p. (in Russian).

Стаття надійшла до редакиії 08.02.2021 